\title{
Using Local Drama in Writing and Speaking: EFL Learners' Creative Expresssion
}

\author{
Dwi Astuti Wahyu Nurhayati \\ Institut Agama Islam Negeri Tulungagung, East Java Indonesia \\ Email: dwiastuti_76@yahoo.co.id/dwiastuti507@gmail.com
}

\begin{abstract}
Creating encouragement among students to speak up and to write is not easy. It is seen on their responses of joining speaking and writing class; most students suppose that speaking and writing English are difficult especially to utter and organize their ideas freely. Problems of speaking include inhibition, nothing to say, low participation, mother-tongue use; writing problems include they lack ideas, organizing of ideas, rhetoric or pattern of thought, cohesion and coherence. However to cope with these problems, this study offers the variation performance in delivering ideas or activities through writing a script and conducting a drama. The steps of learning writing are (1) Creative Expression (responding to the ideas that learners produce; (2) Composing Process: planning-writing-reviewing framework using dramatic structure: orientation, complication, sequence of events, resolution and coda; (3) Genre and context of writing (Building Knowledge of Field (BKoF), Modeling of Text (MoT), Joint Construction of Text (JCoT), and Independent Construction of Text (ICoT and Local Drama as their creative expression: Learners use pattern they have developed to write a script). In speaking, before conducting the performance the students are divided into some groups to create the learning community, the steps are: create script based on themes, next consult the script (discuss their creative expression), observe the characters play, their characterization, mime, and other aspects, practice the script, and finally perform drama outdoor. As the
\end{abstract}


result they become more self-confidence to utter ideas, expressive including writing a script, drama is considered as an appealing learning strategy which promotes not only goal-oriented learning but also emotional intelligence skills.

Keywords: teaching, writing and speaking, drama

\section{INTRODUCTION}

Creating encouragement among students in State Islamic Institute of Tulungagung, a small district in East Java- Indonesia to speak up and to write is not easy (English Department students, 2015). It is seen on their responses of joining speaking and writing class; most students suppose that in school and in life, students face a diversity of circumstances that require language skills. For this reason, experience with a variety of reading, writing and speaking, listening activities in school can help learners acquire the skills they need to be successful. They need, for example, to practice varied kinds of speaking. One of the basic problems in foreign - language teaching is to prepare learners to be able to use the language. How this preparation is done, and how successful it is, depends on very much on how we as teachers understand our aims (Bygate, 2000: 1). For instance, it is obvious that in order to be able to speak a foreign language, it is necessary to know a certain amount of grammar and vocabulary. It means that grammar and vocabulary plays important role to conduct communication or in other words the lack of practicing this skill arises some problems to the students.

Seeing the fact that speaking as one of often becomes a difficult problem for students in conducting communication. Some difficulties which are faced by them such as first they feel shy, afraid of making mistakes, and get stumbling when they utter ideas. Besides that lack of curriculum emphasis on speaking skills such, teachers 'limited English proficiency, class conditions do not favour oral activities, limited opportunities outside of class to practice, and examination system does not emphasize oral skills finnaly the supporting environment does not provide in conducting communication.

The first problem, the students feel shy when they must speak up in front of the class, they are also afraid of making mistakes when they deliver their ideas in conducting interaction with others. Because of lack of practicing or uttering ideas, getting interaction using English makes them get stumbling. They are shy and lazy to speak up using English. Besides that the lack of curriculum which emphasises on speaking skills, the students of English Department, State Islamic Institute of Tulungagung, not only get English skills, but they also get religious subjects. The practicum of Speaking is also omitted because the reason that there is efficiency of any education fund from The Ministry of Religious.

The second problem is the teachers' limited English proficiency, it means that most of English teachers do not have various technique to teach English 
speaking, they only conduct traditional or classical teaching technique. That is why most of the teaching learning process in speaking skill will not be interesting. The students will also not be encouraged to join the class. It also arises other problem, the class conditions do not favor oral activities, it means that the situation of class does not support the students become active in conducting or participating the activity in class, it could be the technique which is used to teach them could not energize them so they are passive and discouraged.

The fourth is limited opportunities outside of class to practice, not many classes in Indonesia conduct teaching learning process outside class or outdoor learning, they say that it costs expensive and time consuming. Even though it is seen that not all outdoor learning costs expensive. It depends on the teacher's creativity to manage any learning process. The other is examination system does not emphasize oral skills. It is true that the examination system do not match with the material given so it needs adjustment from the teacher or lecturer to adapt the system of examination in order that the goal of speaking skill will be reached based on the precise criteria or parameter.

The last problem is the supporting environment does not provide in conducting communication. It means that most of teaching learning in speaking skill does not provide the supporting environment, it could be the real interaction of using English does not happen between the learning society. English is not used in daily activities then the language users will lose their vocabulary.

Language users sometimes fear the challenge of sustained, formal speaking before large groups. Teachers can help reduce unrealistic fears by pointing out how common they are among people and what to do about them. They can also help to reduce such fears by maintaining a friendly atmosphere in the class and providing opportunities for students to practice alone or with one other student and then before increasingly larger groups. Thus, students can practice speaking in front of their peers who face the same situation. Students can practice presenting information, answering questions and holding group discussions. Frequent classroom presentations and discussions enable teachers to diagnose and remedy problems. Students can gain benefit from learning by setting themselves presentation goals and assessing their own progress. Observing proficient speakers can help students to set such goals. Practicing oral presentation in these ways can lessen students' anxieties while, at the same time, helping them to learn the subject matter of the lesson. Students are less likely to be fearful and anxious and more likely to do well if they are well prepared. Preparedness can be enhanced by in-depth mastery of the subject matter, appropriate organization and rehearsing the presentation. It is necessary to provide opportunities to practice speaking because English skill must be mastered by students.

Problems of speaking include inhibition, nothing to say, low confident or uneven participation, mother-tongue use. The students do not want to speak English because they are too shy to talk in English, they are afraid of making 
mistakes or their friends will laugh at them, and they are also anxious because they had not many changes to speak or because the teacher always gave critics and correction on their mistakes right away (Fauzan, 2014; Fauzan, 2016; Karsono, 2014; Ningsih, 2015).

The writing problems include they lack ideas, organizing of ideas, rhetoric or pattern of thought, cohesion and coherence. It is necessary to create an inspiring and supporting situation of speaking and writing class. The characteristics of a successful speaking are learners talk a lot, participation is even, motivation is high, and language is of an acceptable level. In fact to create and encourage the students to do so is not easy. It seems that the lecture needs tobe creative and have a lot of ideas to conduct that (Zuhri Dj \& Sukarnianti, 2015).

There are some relevant previous studies related to this research, Sparch (2004:6) has conducted a research for 34 junior college students in the Applied languages Department at National Formosa University. He found that out of 34 students, 26 students (76\%) gave positive comments on collaborative community and creative drama in helping elementary school students; however, 6 students (17\%) expressed the difficulty of collaborative community because the kids were not serious with the teachers'instruction,time conflict and hard to control of all kids. Then based on kids's questionnaire, two participants (7\%) missed indicating the question,26 students $(6 \%)$ enjoyed the time for drama, they began to grow more interests on English. Futhermore, Miccoli (2001:157) has investigated the effects of drama on the students of English as foreign language in a Brazilian University. She used drama in an oral skill class and cliams that it brought about changes in the perspective and behaviour of not only the learners but also the teacher. It means that drama contributes the improvement of learner's competence in speaking. Students' behaviour changed to become more active in speaking.

Next, Cheng in Hafeez (2010:158) undertakes a study to investigate the students'perception on drama activities in an advanced university English major class. Most of the students felt that drama was useful for oral skills development. Moreover, the students appreciated the fact that they could work with peer who acted as scaffolding for their learning. Drama was also found to be a motivating agent for intercation. The study concludes that through drama activities, they students get extensive speaking practice.

Then, Gray (2002: 88) conducts a cross study analysis of children's writing from five classroom using process drama. The teacher and the students read"Where the Wild Things Are" written by Sendak. After the reading, the teacher put the students in the wild setting asssuming wild roles. Then the teacher and the students discuss their feelings about the activity, jungle and journey, and the new things they had learnt. Having done that, the teacher asked the students to pen down their experiences. The activity revealed that the students took a great interest in the writing activity. All the other classes responded in the similar manner. 
O'Gara in Hafeez (2010: 157) undertakes an experimental stuy to gauge the effectiveness of using drama to teach verb tenses to English as foreign language Italian school students. Though the results are hardly replicable use due to very small class size and an enviable socio-cultural background of the students, the students concludes that the use of drama to teach tenses is more effective compared to the use of traditional methodology. O'Gara found that the student taught through drama were more enthuasiastic than their conterparts in the control group. It is also supported by Nurhayati's study (2008a:126) indicates that the frequency of conducting various games (role play) could make the students more enjoyable to study English especially reducing their burden to join activities. The students were very energetic and they needed some activities that could make them move. It implies that teachers need to be creative in creating the activities for the students, so that the students do not get bored easily. Besides the strengths, the weaknesses that were found in the research such as limited time, the students' ability and motivation, the condition of the teacher who paid more attention to the administrative tasks should be considered to be able to a better teaching-learning process apply the better techniques in order to get the perfect result in improving the students' English vocabulary, spelling and grammar, Nurhayati's other study (2011) implies that to motivate students become a creative writer to write slogan party or party slogan imaginer, the students are given chances to develop their ideas and imagination to write party slogans. It seems that being creative writers could be done by creating political party slogans. Iftanti (2015) added that an inspiring English lecturer is the one who could implement the teaching technique strategies and skills which is changing students' learning style.

Moreover, the up date research of using interesting media to inspire reading comprehension conducted by Nurhayati (2014b) invesigated retelling the ideas and summarizing text using interesting picture series can increase the students'motivation in reading class especially to improve their reading comprehension. They got more strategies to deliver their ideas to other friends after participating in creating picture series and using those reading strategies. The current research investigated by Nurhayati (2015) improving students 'pronunciation abilty through Go Fish and Maze Game; moreover it is also conducted to get more information what activities which make them tend to become more confidence to pronounce some basic words in enjoyable situation conducting these games, using interesting media, creating various interesting tasks and activities can increase the students' motivation in learning English and pronunciation ability

The above-mentioned studies discussed the use of drama and conducting various activities in English Language Teaching but none of them has discussed what text types of drama that have been applied in speaking class or what strategies to integrate drama into learning process have been preferable. Text types of drama and strategies or the way to integrate them into teaching speaking and writing are important part in encouraging them to speak up and write their 
ideas based on the local drama. However to cope with these problems, it offers the variation performance in delivering ideas or activities through writing a script and conducting a drama. It is considered that by conducting those activities it will help the students to be active and creative especially to encourage them to speak up in performing drama (enjoyable condition of learning) and to be creative by writing script of drama. Accordingly, it is significant to conduct a study on using text types of drama or what strategies to teach speaking and writing. The focus of the study was finding out the answer- what the activities on using Local Drama in Teaching Writing and Speaking are.

\section{LITERATURE REVIEW}

Writing is "frequently accepted as being the last language skill to be acquired" (Nunan 1991: 91). It has become a cause of considerable concern that writing is still not playing as full a role as it might in students' literacy and intellectual development. It is one reason to teach writing in relaxed atmosphere in this study.

Teaching writing orientation in this study focuses on creative expression. Elbow and Murray in (Hyland, 2003: 8) propose that many writing teachers from liberal arts background see their classroom goals as fostering L2 students'expressive abilities, encouraging them to find their own voices to produce writing taht is fresh and spontaneous. It means that the classrooms are organized around students'personal experiences and opinions, and writing is considered as a creative act of self -discovey. It helps generate self-awareness of the writer's social position and literate possibilities (Fiere in Hyland, 2003:8) as well as facilites"clear thinking, effective relating and satisfying self-expression" (Moffett, 1982:235). It is also supported by a writing teacher in Japan characterized his approach to challenge the students to be creative in expressing themselves. Students learn to express their feelings and opinions so that others can understand what they think and like to do. The teacher has heard that prospective employers sometimes ask students what they have learned at university, and that some students showed them their poems (Cumming in Hyland,2003: 9).

Seeing from this perspective, writing is learned not taught so writing instruction is nondirective and personal. Writing is a way of sharing personal meanings and writing course emphasize the power of the individual to construct his or her own view on a topic.Teachers see their role as simply to provide students with the space to make their own meanings within a positive and cooperative environment. Because writing is a developmental process, they try to avoid imposing their view, offering models, or suggesting responses to topics beforehand. They should seek to stimulate the writer's ideas through pre-writing task, such as journal writing and parallel texts. Because writing is an act of discovering meaning, a willingness to engage with students'assertions is crucial, and response is a central means to iniate and guide ideas (Straub,2000). This 
orientation further urges teachers to respond to the ideas that learners produce, rather than dwell on formal errors (Murray, 1985).

Dealing with this orientation, this study supposes that expressivism is an important approach as it encourages writers (students) to explore beliefs, engage with the ideas of others and connect with readers. Yet it leans heavily on an asocial view of the writer, and its ideology of individualism may disadavantage second language or foreign language students from cultures that place a diffirent value on self-expression. It simply assumes that all writers have a similar innate creative potential and can learn to express themselves through writing if their originality and spontaneity are allowed to flourish. Murray's (1985) A writer teaches writing, for instance, provides a good account of expressivist methods but also suggests the importance of the teacher's own personal insight process. Some matters which teachers consider in L1 writing classroom, expresssivism has been treated cautiously in EFL contexts. Although many students have learned successfully through this approach, others may experience difficulties, as it tends to neglect the cultural backgrounds of learners, the social consequences of writing, and the purposes of communication in the real world, where writing matters (Hyland,2003: 10).

The process model of writing instruction (a drama script in thi context) as according to Hyland (2003) is characterized by recognizing basic cognitive process as central writing activity and in stressing the need to develop students'abilities to plan, define a rhetorical problem, propose and evaluate solutions which can only be conducted by some of the following deeds:

a. Selection of topic: by teachers and/or students;

b. Prewriting: brainstorming, collecting data, note taking, outlining

c. Composing: getting ideas down on paper

d. Response to draft: teacher/peers respond to ideas,organization and style;

e. Revising: reorganizing, style, adjusting to readers, refining ideas

f. Response to revisions: teachers/peers respond to ideas, organization, and style;

g. Proofreading and editing: checking and correcting form, layout, evidence, etc.;

h. Evaluation: teacher progress over the process;

i. Follow-up tasks: to address weaknesses.

It is further stated that the model of writing process most widely accepted by L2/FL writing teachers is the original planning-writing-reviewing framework (Flower, 1989; Flower and Hayes, 1981). Zamel (1983:165) also supports that writing is seen as a non-linear, explanatory, and generative process whereby writers discover and reformulate their ideas as they attempt to approximate meaning". It shows that some writing process such as planning, drafting, revising and editing do not occur in neat linear sequence but recursive, interactive and 
potentially simultaneous, and all work can be reviewed, evaluated and revised, even before any text has been produced at all. The point is the writer can jump backward or forward to any of these activities: returning to the library for more data, revising the plan to accommodate new ideas, or rewriting for readability after peer feedback.

Parallel to this, Polio (2001) states that process theories alone cannot help teachers confidently advise students on their writing, and one reason why there is little evidence to show that process methods alone lead to significantly better writing. It is quite simply, equipping novice writers with the strategies of good writers does not only necessarily lead to improvement. Students not only need help in learning how to write but also in understanding how text are shaped by topic, audience, purpose, and cultural norms (Hyland,2003)

Specifically, there are some focuses of L2 writing teaching - referring to theories as curriculum options which have a different focus (Cumming in Hyland, 2003:117). They fall within seven orientations, namely, (1) Language structures, (2) Text function, (3) Themes or topics and (4) Creative Expression, (5) Composing Process, (6) Content, (7) Genre and context of writing. The last of three orientations used in this study focus on exploring creative expression, composing process and genre and context of writing.

In the development of the GBA theory, Wray and Lewis (1998) parse that the three-stage model afterwards became a four-part model or called the Teaching and Learning Cycle. The cycle of Teaching and Learning was introduced by Hammond et al in 1992 which includes; Building Knowledge of Field (BKoF), Modeling of Text (MoT), Joint Construction of Text (JCoT), and Independent Construction of Text (ICoT).

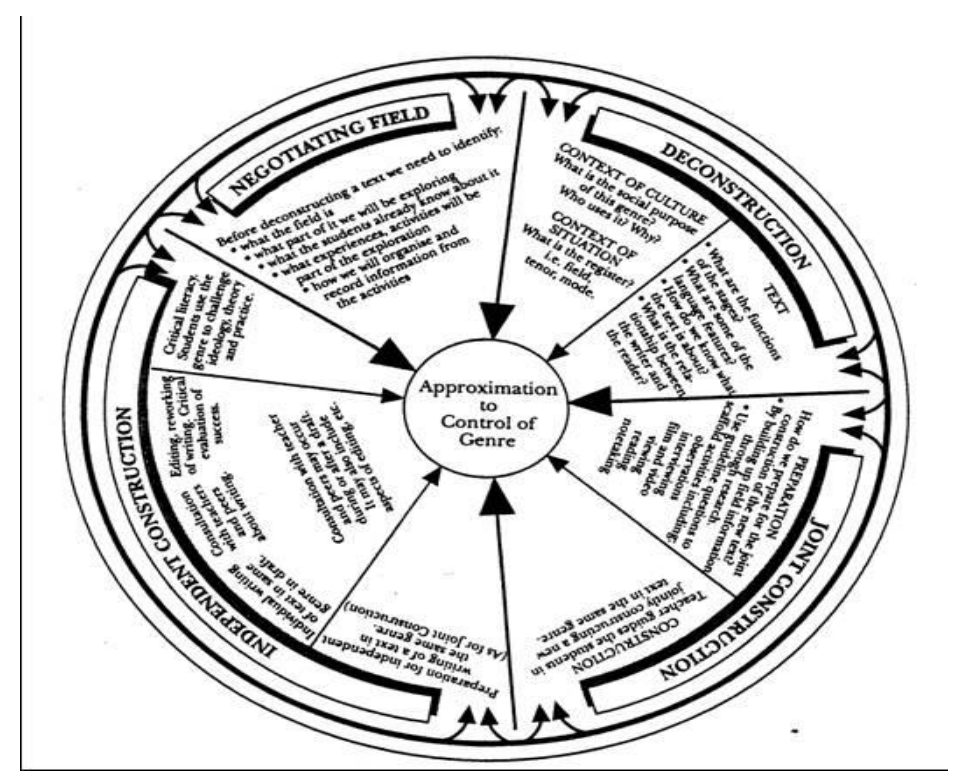

Figure 1: Teaching and learning cycle (Hammond et al, 1992, p. 17) 
Genre-Based Approach offers classroom programming four stages in a Curriculum Cycle or Teaching-Learning Cycle (adapted from Hammond et al, 1992). These stages are identified in the diagram below (figure 1). The selection and sequencing of classroom tasks and starting points of topic or type of text activities are introduced by these stages. The four stages are; 1) Building the context or field of the topic or text-type or Building Knowledge of Field (BKoF): The students can explore cultural similarities and differences related to the topic, practice grammatical patterns relevant to the topic or text type, and build up and extend vocabulary relevant to the topic or text type, 2) Modeling of Text (MoT): It introduces the learners to a model of the genre they will write. It differs from the work done in the first stage, which aims at building students' knowledge of the general context of the topic. Furthermore, Kongpetch (2006, p.12) states that the purpose of this stage was to explicitly teach students the generic structure and grammatical features of the text, so that the students became aware of how it is structured to achieve its purpose, 3) Joint Construction of Text (JCoT): The students gather relevant information, conduct researching the topic through additional reading, or preparing a series of notes to be used as the basis for the text, and 4) Independent Construction of Text (ICoT: It enables students to practice their writing skills and demonstrate their understanding of the report genre writing. Before going to this stage, the teacher has to make sure if the students are ready to construct the text independently. Generally, independent construction occurs only after group or pair construction has shown that the students have gained control of the field and the mode. This stage allows the students increase knowledge and control of the field and the mode as well as the models of texts produced).

One of the skills that play the important rule in learning a foreign language, especially English, is speaking. Learning to speak foreign language requires more than knowing its grammatical and semantic rules language. Learners must also acquire the knowledge of how native speaker use the language in the context of structured interpersonal changes, in which many teachers interact. The ability to speak fluently presupposes not only knowledge of language feature, but also the ability to process the information and language 'on the spot' (Harmer, 2000:269).

The importance of speaking skill in learning foreign language, especially English, demands the teacher or lecturer to be a creative person in order to help his students in learning speaking in English. Unfortunately, up to now what happen in the class is quite different where the teacher is still dominant in the class and gives little chance to the students to speak up.

Seen from point of view of speaking, speaking is "the process of building and sharing meaning through the use of verbal and non-verbal symbols, in a variety of contexts" (Chaney, 1998: 13). It means that speaking is a process of using verbal and non-verbal symbols in any context. Although speaking is totally natural, speaking in a language other than our own is anything but simple. 
Speaking is a crucial part of second language learning. Despite its importance, for many years, teaching speaking has been undervalued and English language teachers have continued to teach speaking just as repetition of drills or memorization of dialogues (Celce, 2001: 164).

Speaking as a fundamental to human communication means that speaking is used to interact and communicate by someone to others (Allen, 1985: 97). In all of life activities of course, speaking is needed. Although written language communication can be used in daily life, but speaking has more capacity of the use in daily life for example, to call or greet. It also makes easier for the user to conduct communication. In speaking activities the students usually get some problems that make them difficult to speak or say anything. Sometimes it can be hoped based on many reasons. They can feel shy or lack of vocabulary.

Speaking is a productive skill. It involves putting a message together, communicating the message, and interacting with other people. Speaking involves at least two people, a speaker and listener (Lindsay and Knight, 2006). In real life, they discuss each other, exchange information about what they see and hear, etc. Besides that, speaking is oral language skill that involve knowledge and pronunciation, grammar, vocabulary, and culture. The students who want to be able to speak fluently in English, they need to be able to pronounce phonemes correctly, use appropriate stress and intonation patterns and speak in connected speech. But there is more than that, speakers of English especially they use English as a second language will have to be able to speak in range of different genres and situations and they will have to use a range of conversational repair strategies. The students will need to be able to survive in typical functional exchanges.

Harmer (2005: 13-14) suggests different speaking events in order to describe different speaking. Whatever the purpose speaking events, people can characterize it as interactive or non interactive. Finally, people might be difference between speaking that is planned and speaking that is unplanned, such as a job conversation that takes place spontaneously when we bump into someone on the street. It means that using different events will describe different speaking.

Some speaking in job interview may be for the exact purpose of maintaining and sustaining good interpersonal relations, and most interview do their best to plan what they are going to say just as interviews plan what some their questions will be (Harmer, 2004: 233). Nevertheless, thinking of speaking in terms of purpose, participation, and planning helps the people speaking activities in all six categories and in different combinations of these categories. $\mathrm{He}$ (2004: 225) further mentions that successful interaction depends on a knowledge and successful execution of turn taking. In other words, conversation can be successful which the students need to be able to ask for repetition by using formulating expression repeating up to the point of the conversation breakdown. In real talk, the students are involved in spontaneous face to face 
conversation outside the classroom with English language speakers, people probably need to be expected to more than just the kind of question found in cookbooks. However, the students need to be aware of what real conversation to like and the teacher should give students help in using some of the more important phrases. Each student has to pick up one of the strips and they then have learned the phrase on it in conversation.

When teaching speaking, the teacher needs to make students aware to fixed phrases, functional sentences and adjacency pairs. Teachers can do this by teaching functional exchanges. Teachers can do this by teaching functional exchanges. Teachers can have students look at transcripts of typical exchanges and teacher can let them watch film clips of this kinds language use.

According to Richards (in http://www.professorjackrichards.com) there are some aspects in oral fluency or speaking, they include; use of conversational routines, using conversational routines is suggested to the students then they will be used to uttering their daily activities, or ideas related to their activities, then use of short and long turns, it will be effective for the student to use the short and long turn because it makes the students try to understand the meaning of the utterances that they deliver to, next topic range, it is better to consider the topic range especially the most interesting and current topics for the students. It makes them to be encouraged to deliver their ideas, creativity and imagination, mastery of basic functions, in this case, the mastery of basic function in language will be important for the students. They will know how to use the language for communicative function or transactional function which will be different in using both of them, finally use of adjacency pairs, the use of adjacency pairs also need for them, because by using the adjacency pairs, they will know the context of the conversations.

Then the features of interaction consists of three aspects, they are create social interaction, it means that by conducting interaction between the speaker and hearer it will create social interaction, because the interaction of two people or more will involve any people from different social class. They could be from the high social class, middle or lower class which have different terms, background knowledge or colloquial, then address the face needs of participants, in this case in conducting interaction, it will address the face needs of participants, most of them conduct interaction by face to face, the last focus on participants and their social needs, in other words the interaction must be focused on who are the participants and what are their social needs such as association, networking and others.

Teaching speaking is a challenging responsibility as there are many problems related to every day practice. According to Ur (1996: 121) some fundamental problems that appear in the speaking class include inhibition, complete silence, and low participation. Learners often feel afraid to say things in foreign language classroom. They are usually worried in making mistakes fearful of criticism or losing face, or simply shy of the attention that their speech attracts 
(Cahyono, 2000: 15). In addition, learners often complain that they cannot think of anything to say; they have no motive to express themselves beyond the guilty feeling that they should speak up. In the speaking class, only one participant can talk at a time if the students to be heard. In a large group, it means that each participant will have only very little time to talk. The problem is compounded by the tendency that some learners are dominant, while others speak very little or not at all. In another case, there is a tendency for them to use mother tongue because it is easier.

The teacher is expected to design an activity that will be able to overcome those problems. Ur (1996: 120) suggests four characteristics of successful speaking class. First, much of the time should be used for the activity involving the learners to talk. Second, classroom activity should not be dominated by talkative participants. All learners should get a chance to speak and contributions are distributed evenly. Third learners are eager to speak because they are interested in the topic. Learners have something new to say about it or because they want to contribute to achieve a task objective. Last, the learners express themselves in utterances that are relevant, easily comprehensible to each other, and of an acceptable level of language accuracy. One of the ways to realize a successful speaking class is through task based on language learning. So, any four characteristics of successful speaking class, the students must have activity to improve their speaking class, the students must be diligent to improve sentences in any topics. The students should be having new creativities to achieve task objective, and the students must express their skill in level speaking. From the explanation above by designing the attractive activities, it is hoped that the successful speaking class can be reached.

Speaking is important part of the learning and teaching process of English as second language. Despite its importance, for many years, teaching speaking has been undervalued because English teachers continually teach speaking just as a repetition of drills or memorization of dialogues.

Nowadays, however, the goal of teaching is shifted to improve students' communication skills, because, only in that way, the students can express themselves and learn how to follow the social and cultural rules appropriate in certain circumstances. According to Indrawati (in http:// efidew.wordpress.com. retrieved 7 June, 2008/activities-in-teaching-speaking). There are several activities to teach second language learners how to speak communicatively.

1. The first activity is discussion, it aims at drawing a conclusion, sharing ideas about something, or finding solution on a problem. In this activity, a teacher must set the purpose of discussion in the beginning so that the students will discuss relevant points based on the purpose. In addition, they will not spend their time chatting each other about irrelevant and unnecessary things.

2. The second way of setting students to speak is role play and simulation. In role play activities, the students pretend they are in a various contexts and 
have a variety of social roles. The teacher then gives information to learners such as who they are and what they think or feel. For example, the teacher can tell the student," Andy, you go to an accountant and tell him what happened to your business last month." Simulations, on the other hand, are elaborations of role play, because the students can bring items to class to create a realistic environment. For instance, if a student becomes a doctor, he brings a stethoscope to examine his patients and so on. Role play and simulation have advantages. For one, it is entertaining as well as motivating students. The second advantage is increasing the self-confidence of hesitant students, because they have a different role, and do not have to speak for themselves, it means that they do not need to feel ashamed of making mistakes.

3. The third activity is brainstorming; in this case students must produce ideas on a given topic in a limited time. Brainstorming is one of very effective way to the encouraged students to speak up their thoughts and feelings quickly and freely. The good characteristics of this activity is that the students are not criticized for their ideas, so students will be open to share new things collaboratively.

4. The fourth and the most favorite, his opinion, is storytellig. The students can summarize a tale or story heard from somebody before they may create their own stories to tell to their classmates. These students have creative thinking, because they must organize the story in the format beginning, development, and ending. In addition, the students must be able to describe characters and the setting of the story very clearly. By conducting this, the teacher can both explore students' speaking and entertain the class.

5. The last activity is reporting, which integrates students reading and listening skill with speaking ability. Before coming to class, the students are asked to read newspaper or magazines, or to listen to news on radio or television. Later in class, they report to their friends what they find as the most interesting news or tell whether they have experienced anything related to the news worth telling to class. This activity fosters the creativity of the learners as well as their public speaking skills.

From those speaking activities, this study focuses on the second activities which use drama or role play to conduct speaking class. Besides that, it can be said that drama has many strengths to be conducted in speaking class.

Genre used by the students in this study is dramatic text, a dramatic text uses acting to communicate ideas and experiences. Dramas can be spoken or written. They may have set lines or the actors can improvise (make up the lines they go along). The purpose of drama is to express the dramatist's idea so as to make the audience think about life. Drama uses dialogue (spoken words), actions and visual elements (facial expressions, costumes, sets, etc.) to help 
communicate meaning. The examples of dramatic texts are film scripts, improvisations, stage settings, soap opera, street theatre, re-enactments. Dramatic text may be in the form of script which includes an introduction men (telling the background to the drama, previous production of the drama and instructions for performances of the drama) followed by segments of actions set out in acts and scenes. Within the drama there can be narratives, poems, monologues and verse. The structure can be similar to a narrative: orientation, complication, sequence of events, resolution and coda Mark \& Kathy, 1998: 9-19). Instead of considering those steps, it also concerns about the introductory paragraphs of dramatic entrance which it is often useful to begin with a description of a scene that establishes the need for a process of story ( Smalley, Ruetten \& Kozrev, 2001: 234).

There are many reasons in favour of using drama activities and technique in language classroom. First of all it is entertaining and fun, and it provides motivation to learn. It can provide varied opportunities for different uses of language and because it engages feelings it can provide rich experience of language for the participants.

There are many points supporting the use of drama and these are as follows lists: 1) It integrates langugae skills in natural way. Careful listening is a key of feature. Spontaneous verbal expression is integral to most of the activities; and many of them require reading and writing, both as part of the input and output. 2) It integrates verbal and non verbal aspects of communication, thus bringing together both mind and body, and restoring thre balance bteween physical and intelectual aspecs of learning. 3) It draws upon both coginitive and affective domains, thus restoring the importance of feeling as well as thinking. 4) By fully contextualizing the language, it brings the clasroom interaction to life through an intensive focus on meaning. 5) The emphasis on whole-person learning and multi-sensory inputs helps learners to capitalize on their strength and to extend their range. In doing so, it offers unequaled opportunities for catering leraner differences. 5) It fosters self-awareness (and awareness of others), self-esteem and and confidence, and through this motivation is developed. 5) Motivation is likewise fostered and susutained through the variety and sense of expectancy generated by the activities. 6) There is a transfer of responsibility for learning from teacher to learners which is where it belongs.7) It encourages an open, exploratory style of learning where creativity and the imagination are given scope to develop.This in turn, promotes risk-taking, which is an essential element in effective language learning. 8) It has a positive effect on classroom dynamics and atmosphere, thus facilitating the fromation of a bondel group, which learns together. 9) It is an enjoyable experience. 10) It is low -resource. For most of the time, all you need is a 'roomful of human beings' (Maley, 2005).

Besides, some research studies, (Maley and Duff, 2001, Philips, 2003) suggest that drama activities can promote interesting ways of motivating 
language learners and teachers. With drama we play, move, act and learn at the same time (Philips, 2003). There are several studies that support the benefits of drama in foreign language learning, such as Maley and Duff (2001), Brumfit (1991) and Philips and Cheng (2004). Dramatic activities according to Maley and Duff (1979) "Are activities which give the students and opportunity to use language expressing various emotion, to solve problems, to make decisions, to socialize.

There are different ways in which drama can be defined and to mention only one of them, (1982) takes drama to mean" any kind of activity where learners are asked either to portray themselves or to portray someone else in an imaginary situation". In other words, drama is concerned with the world of "let's pretend"; it asks the learner to project himself imaginatively into another situation, outside the classroom, or into the skin and persona of another person". It means that by conducting drama, it asks students to play role as the characters that they should perform. As mentioned before drama can foster the oral communication of the students, let's us now find out how drama can do that. Using drama and drama activities has clear advantages for language learning. It encourages students to speak; it gives them the chance to communicate, even with limited language, using non verbal communication, such as body movements and facial expression. There are also a number of other factors which makes drama a very powerful tool in the language classroom. Desialova (2009) outlined some of the areas where drama is very useful to language learners and teachers, and they are listed below: 1) to give learners an experience (dry-run) of using the language for genuine communication and real life purposes; and by generating a need to speak. Drama is an ideal way to encourage learners to guess the meaning of unknown language in a context. Learners will need to use a mixture of language structures and functions ("chunks") if they want to communicate successfully. In other words, by conducting drama makes language learning an active, motivating experience, it also help learners gain the confidence and self-esteem needed to use the language spontaneously.2) To bring the real world into the classroom (problem solving, research, consulting dictionaries, real time and space, cross-curricular content) When using drama the aim can be more than linguistic, teachers can use topics from other subjects; the students can act out scenes from history, they can work on ideas and issues that run through the curriculum. Drama can also be used to introduce the culture of the new language, through stories and customs, and with a context for working on different kinds of behavior.

\section{RESEARCH METHOD}

This study which is aimed at describing the students activities in writing script of local drama and act out the drama were done through observation. It applies qualitative approach (Creswell, 2003); it is intended to figure out the the students' activities in conducting the steps of writing the script and conducting 
local drama. The subject of this research was the Fourth Semester students of English Department at State Islamic Institute of Tulungagung-Indonesia. There were 50 students who joined the Speaking class. There were 50 females, and 15 males. Most of them come from Tulungagung. It was conducted for four months, from March until June 2015.

The instruments of collecting data are observation, interview and documentation. The first data is observation, in which the subjects were observed in the beginning of lecturing, the subjects were observed in the beginning of lecturing until the end of lecturing by conducting these steps as follows: : 1) create the learning community, 2) the steps are: create script based on themes (romance, humor, folklore, horror, legend) 3) the students consult the script to the lecturer (revised grammatically and semantically)before performing the drama observe any dramas (observe the characters play their characterization, mime, and other aspects), practice the script regularly, 4) perform drama outdoor (it could be on the stage in campus).

In the documentation, firstly they collected their scripts after they conducted observation other dramas. They observed other dramas to know about the characterization, improvisation, mime, expressions, setting, sounds and others. The next for the interview the researcher got a lot information from the students. By conducting this technique, most of students said that it contributed their speaking ability and also their writing skill, especially writing script needed their writing skill especially about genre based writing, willingness, concentration, imagination to create the script. They also said that it was a new situation of learning for them, because they have never conducted such observation like this before. Then there were so much information and knowledge that they knew such as how to create script and perform a drama. It improved their knowledge about conducting and performing characterization. It also increased their self confidence to perform in fornt other friends that it would help them to reduce their nerve to teach their students in the future. The collected data were analysed by using qualitative descriptive analysis which were done through some steps according to Bodgan \& Biklen (1982) as follows: 1. Reading and learning the data, signalling the key words and ideas in those data; 2.Learning the key words which represented the themes of data; 3.Writing the models from the findings; 4.Coding. This study uses the technique of qualitative descriptive analysis including data and information which were got directly from the respondents then analyzed using theoretical review and describe the facts systematically.

\section{FINDINGS AND DISCUSSION}

The findings of this study show on how to teach writing script in English by encouraging the students' employment of genre and steps of writing and perform their creative expression by conducting drama. The teaching procedure 
applied here reveals how the concept of genre works and how should be selected in writing news.

In the process of observing the steps of teaching writing, it found that the students actually review their knowledge in writing narrative text or genre by conducting the steps as follows; 1) Building Knowledge of the Field. The focus of genre is narrative, one of them is dramatic text, the students should identify the topic of the text, whether text is about Ande-Ande Lumut or Malin Kundang. The next step is to give students the experience about the content of the text. The activities are in form of questions and answers about the narrative texts which have been read by the students to enlarge vocabulary, 2) Modelling text, in this stage the lecture gives example of the text. For written cycle the activities are reading comprehension, procedural knowledge or text organization are introduced in this stage; 3)Joint construction of the text, in this stage the lecturer builds students self confidence in productive skills either speaking or writing. For this purpose, the lecturer gives opportunity to students to cooperate in pair or in group (the script can be read by peer. The example activities for spoken cycle are role play, discussion; 4) Independent Construction, the purpose is to know how far the students master the lesson individually and students must have the responsibility for their own learning.

In writing the script, all the groups write their own dialog, the source can be taken from legend, folktales, teenage story in the local context, some of groups combine their own ideas and the ideas from film. Beside using the writing steps, they also use their imagination in order to entertain to refresh the situation so that the story are written humorously without reducing the moral values which they want to deliver to the audience.

Most of the students after conducting the steps of speaking activities, observing other drama, consulting script based on themes, including performing drama outdoor say that they become more active and creative to speak up in English, they can express ideas using mimic, better pronunciation, more vocabulary, then some of them say as candidate of teacher, they should perform in front of their students, by conducting drama, it helps them to minimalize nerves tobe enjoyable in front of the public including the students will be.

In interviewing, the study reveals that conducting observation before performing the drama improve their literature knowledge by reading the script, and seeing other dramas. They also learn to play the drama by seeing film firstly or other dramas in order to know how to play the characters well and make the audience impressed. Beside that they take certain points, for example performing good characterization based on their characters on the stage, in order that they can minimalize the mistakes on the stage such as blocking and others, mostly they may conduct improvisations to perform on their own creation.

In observing the students learning process, it found that in creating the script some groups need long enough time because they have to play their imagination to compose sequence of events, in certain case, it doesn't imply for a 
few groups, they only needs three or two hours if they do it seriously. Writing drama script not only improves their knowledge about how to write script but also express their English theoretical along they got in joining writing subject.

Most of the students say that they get different experience from routines, they feel enjoyable, excitied, encouraged then the most important thing is it increases vocabulary, pronunciation, their self confidence. It also reduces their nerves to performance it in outdoor because the audience are not only from their classmate but also from other classes. It practices them to adapt with the English expressions beside that they must know the context of drama. By conducting drama they could learn how to establish good teamwork to perform drama solidly, whereas they also become more self confidence to show their own their creativity.

This study has conceptualized a two-fold idea that a peer response (group) is considered very important for the students. Peer response is not only applied during the proofreading, but also in the class discussion or group presentation. The most important thing is that it gains students' confidence, perspective, and critical thinking skills which rise students' motivation in writing skill. Firstly,it can be shaped by conducting these steps as follows: writing a creative exppresion text, composing (1) Creative Expression (responding to the ideas that learners produce; then (2) Composing Process: in this steps, learners are guided by the lecturer to conduct planning-writing-reviewing framework using dramatic structure: orientation, complication, sequence of events, resolution and coda; using (3) Genre and context of writing (Building Knowledge of Field (BKoF), Modeling of Text (MoT), Joint Construction of Text (JCoT), and Independent Construction of Text (ICoT and Local Drama as their creative expression: Learners use pattern they have developed to write a script). Secondly,in speaking, before conducting the performance the students are divided into some groups to create the learning community, the steps are: create script based on themes, next consult the script (discuss their creative expreesion), observe the characters play, their characterization, mime, and other aspects, practice the script, and finally perform drama outdoor.

This supports Ferris provides an argumentation that peer-response will give a number of benefits since students get more feedback from more diverse audience which bring multiple perspective (2003). Afterwards, the students could consult with teacher individually as they required assistance or feedback. The teacher's role is to provide constructive comments to the learners on what further development may be necessary. As Hyland states above, the teacher has a central role in "scaffolding" this development. It shows that the teacher is the facilitator and the guidance during the writing activities. Thus, the GBA was considered very effective to implement in writing class. Dealing with this result, Fleming, (2006) who found drama is an inevitably learner-centered because it can only operate through active cooperation. It is therefore a social activity and thus embodies much of the theory that has emphasized the social and communal, as 
opposed to the classroom provides exciting opportunities for foreign language learners to use the language in concrete "situations". Also the use of drama activities has clear advantages for language learning regarding motivation, the use of language in context, teaching and learning cross curricular content, etc (Philips, 2003).

\section{CONCLUSION AND SUGGESTION}

Based on the findings, the conclusion of this study is drawn. The steps of learning writing are (1) Creative Expression (responding to the ideas that learners produce; (2) Composing Process: planning-writing-reviewing framework using dramatic structure: orientation, complication, sequence of events, resolution and coda; (3) Genre and context of writing (Building Knowledge of Field (BKoF), Modeling of Text (MoT), Joint Construction of Text (JCoT), and Independent Construction of Text (ICoT and Local Drama as their creative expression: Learners use pattern they have developed to write a script). In speaking, before conducting the performance the students are divided into some groups to create the learning community, the steps are: create script based on themes, next consult the script (discuss their creative expression), observe the characters play, their characterization, mime, and other aspects, practice the script, and finally perform drama outdoor. As the result they become more self-confidence to utter ideas, expressive including writing a script, drama is considered as an appealing learning strategy which promotes not only goal-oriented learning but also emotional intelligence skills.

Indeed, in addition to possess a wide range of adding the learners' writing and speaking qualities, the result of the study also sheds a new technique, establishing teamwork especially to write script, share their knowledge about the local drama in their culture and combine their creativity by observing other dramas before performing the drama and conducting some steps. They can be more creative, iniatitive then responsive in performing the local drama in contemporer style. They also try to entertain the audience without reducing the moral values which they deliver.

Accordingly, it is suggested that to be creating and motivating learners, an EFL lecturer is supposed to sustainably improve his/ her strong teaching technique or strategies. Moreover, the institutional education running an English education program should openly support the improvement of the EFL learners to provide their crative expression to write a script and develop theater activities. Since this study only focuses on using local drama in writing and speaking to gain or explore EFL learners' creativity, further researcher is suggested to conduct a study with more technique, local culture and skills selected from various contexts to get more comprehensible idea of what activities should the EFL learners and lectures' strategies to use. 
Using Local Drama in Writing and Speaking

\section{REFERENCES}

Allen, Virginia French. (1983).Technique in Teaching Speaking. New York: Oxford University Press.

Anderson, Mark \& Kathy. (1998).Text Types in English 3.Australia: McMillan Education Australia Pty. Ltd. pp.9.

Barbu, Lucia. (2007). Using Drama Techniques for Teaching English. Retrieved on 17/7/2010 from http://forum.famouswhy.com/index.php

Blatner, A. (2002). Role playing in Education, Retrieved on 1/8/2010 www.blatner.com/adam/pdntbk/rlplayedu.htm.

Bodgan, R.C, Biklen, S. K. (1982). Qualitative Research For Education: An Introduction to Theory and Method. Boston: Ally \&Bacon, Inc.

Brumfit, C. (1991). The Communicative Approach to Language Teaching. Oxford: Oxford University Press.

Bygate,M. (2000).Speaking. New York Oxford University Press.

Cahyono, Yudi Bambang. (2000). The Teaching of English Langugaes Skills and English Language Components. Malang:State University of Malang Press.

Celce-Murcia. M. (2001). Teaching English as a Second or Foreign Language $(3 r d E d)$. USA: Heinle\&Heinle.

Chaney, A.L., and T.L. Burk. (1998). Teaching Oral Communication in Grades K-8. Boston: Allyn \&Bacon.

Cheng,Michael. (2007). Student Perceptions of Interactive Drama Activities. Journal of Interactive Drama, Vol.2.3, November,2007.

Cresswell, John.W. (2003). Research Design: Qualitative, Quantitative, and Mixed Methods Approaches.London: Sage Publishing.

Department of School Education. (1991). Literacy and Educational Research Network NSW.pp.16.

Desialova, Liubov. (2009). Using different forms of Drama in EFL. Classroom. Humanizing LanguageTeaching Magazine, issue 4 Retrieved on 17/7/2010 from http://www. hltmag.co.uk/aug09/sart07.htm.

Fauzan, Umar. (2014). The Use of Improvisation technique to improve the Speaking ability of EFL students. DINAMIKA ILMU. Vol. 14 No. 2, 2014

Fauzan, Umar. (2016). Enhancing Speaking Ability of EFL Students through Debate and Peer Assessment. EFL JOURNAL, Vol 1. No 1, 2016

Ferris, D. (2003). Response to student writing: Implications for second language students. Mahwah: Lawrence Erlbaum Associates Inc.

Fleming, Mike. (2006). Drama and Language Teaching: The Relevance of Wittgenstein's Concept of Language Games. Humanizing language teaching Magazine, issue 4.

Gray. (2002). Speaking..https://www.scribd.com/doc/211964504/jurnal-aboutspeakingMarch 12, 2014. Retrieved,24 February,2016.

Hafeez, Muhamad Rashid. 2010. Impact of Dramatics on Composition Skills of Secondary School English Language Learners in Pakistan. Language in India www.language.einindia.com10:march 2010. 
Hammond, J., Burns, A., Joyce, H., Brosnan, D., \& Gerot, L. (1992). English for specific purposes: A handbook for teachers of adult literacy. Sydney: NCELTR.

Harmer, Jeremy. (2005). How To Teach Speaking. England: Pearson Educated Limited.

Holden, Susan. (1982). Drama in Language Teaching. London. Longman. http://teacherlingo.com/blogs/makeadifference/archive/2009/02/02/effecti ve-uses-of-drama-inthe-language-classroom-nigel-a-caplan.aspx Retrieved,24 February,2016.

Hyland, Ken. (2003). Second Language Writing. New York: Cambridge University Press.

Iftanti, Erna. (2015). Investigating Inspiring English Lecturers in a Faith-Based Educational Institution: EFL Learners' Perception. Dinamika Ilmu, Vol. 15 No. 2, 2015

Indrawati, Efi Dyah. (2008). Activities in Teaching Speaking. Kahyi, Hayriye, posted in academic writing bookmark the permalink in http:// efidew.wordpress.com. retrieved 7 June, 2008.

Karsono, Puguh. (2014). Using Pictures in Improving the Speaking Ability of the Grade Eight-A Students of SMP Negeri 1 Anggana. Dinamika Ilmu, Vol 14 No 2, 2014

Kongpetch, S. (2006). Using a genre-based approach to teach writing to Thai students: A case study. Prospect, 21(2), 3-33.

Lindsay, Cora and Knight,Paul. (2006). Learning and Teaching English: A Course for Teachers. Oxford: Oxford University Press

Maley,A and Duff,A. (1978) (2End Edition). Drama Techniques in Language Learning. Cup.

Maley,Alan and Alan Duff. (1984). Drama Techniques in Language Learning: A Resource Book of Communication Activities for Language Teachers. Cambridge.

Malley, Alan. (2012). Creative Writing for Students and Teachers. Major Articles.Year14;Issue3; June 2012, ISSN 1755-975 Retrieved 26, June 2012.pp.2.

Miccoli,Laura. (2001).English Through Drama for Oral Skills Development Retrieved, 24 February, 2016 from http://biblioteca.uqroo.mx/hemeroteca/ elt_journal/2003/abril/570122.pdf.

Murray, D.(1985). A Writer teaches writing.(2nd ed.)Boston: HoughtonMifflin.

Ningsih, Suma. (2015). Meningkatkan Kemampuan Speaking Siswa-siswi Madrasah melalui Role-Play. INNOVATIO, Vol 15. No 1, 2015

Nunan, D., (2003). Practical English Language Teaching. NY: McGraw-Hill.

Nurhayati, Dwi Astuti Wahyu. (2008a). Improving Students'English Vocabulary Mastery through Games (A Classroom Action Research in the Islam Kindergarten of Al-Irsyad Madiun in the Academic Year 2007/2008). Surakarta. Graduate School of Sebelas Maret University. 
Nurhayati, Dwi Astuti Wahyu. (2011). Being A Creative Writer: Party Slogan Imaginer. 2011 Asia Creative Writing Conference 31 March-1April 2011.Department of English Jember Polytecnic, East Java Indonesia.

Nurhayati, Dwi Astuti Wahyu. (2014b). Using Picture Series to Inspire Reading Comprehension for the Second Semester Students of English Department of IAIN Tulungagung. Dinamika Ilmu Journal.Vol.14.No.2.Desember 2014: 176-189.

Nurhayati, Dwi Astuti Wahyu. (2015). Improving Students' English Pronunciation Ability through Go Fish Game and Maze Game. Dinamika Ilmu Journal.Vol.15.No.2.Desember 2015: 215-234.

Philip,B. \&Cheng,M. (2004). Interactive Drama: Freeform Live Action Role Playing Games for the Classroom. Selected Papers from the Thirteenth International Symposium on English Teaching (pp.236-248) Taipei: English Teacher's Association of the Republic China.

Polio, C. (2003).An Overview of What We Investigate and How. In B.Kroll (ed). Exploring the Dynamics of Second language Writing. New York: Cambridge University Press.

Richards, Jacks. (2012). Teaching Speaking Theories and Methodologies. Retrieved 24 February,2016http: www.professorjackrichards.com.

Smalley,et al. (2001). Refining Composition Skills: Rhethoric and Grammar. USA: Heinle \&Heinle-Thomson Learning.

Spach. (2004). Creative Drama in English Learning: a Study of College Students Applying English Dramas in Elementary School Students. http://sparc.nfu. edu.tw/ tsc/encouraging/94/TCS049.pdf.

Straub,R. (2000). The Student, the text, and the classroom context: a Case Study of Student response. Assessed in Writing,7.23-55.

Ur,Penny. (1996). A Course in Language Teaching: Practice and Theory. Great Britain: Cambridge University Press.

Wray, D., \& Lewis, M. (1998). An Approach to Factual Writing. Retrieved from http://www.hltmag.co.uk/apr09/mart02.htm

Zuhri Dj, Muhammad \& Sukarnianti. (2015). Using Hypnoteaching Strategy to Improve Students' Writing Ability. Dinamika Ilmu. Vol. 15 No 2, 2015

Zyoud, Munther. (2009). Using Drama Activities and Techniques to Foster Teaching English as a Foreign Language: a Theoretical Perspective. AlQuds Open University. pp.6. 
Appendix 1

The students' Local Drama Script ( before reviewing phase)

\section{ANDHE-ANDHE LUMUT (GALAU)}

The story was happen in a small village in middle of Java (Central Java). There was lived a prince who always confuse because he didn't have a couple. And there was a beautiful girl who has two bad step sisters. The story was beginning when Yellow lost one of her slipper in the river, because her slipper drift in the river and he found her slipper and he wanted Yellow to be his wife. Andhe gives announcement that he would conduct a prize contest to find the girl who has a couple of that slipper; she would to be Ande-ande's wife. While, Yellow's step sister also wanted to marry with Ande-ande, so they stole yellow which just one side. Then, they brought the slipper to follow that prize contest. On the way they meet with Yuyu Kangkang who would across the river. When they arrived at Andhe's house, they showed the couple of slipper which found by Andhe, but Andhe did not accept them to be his wife because they were kissed by Yuyu Kangkang. While, Yellow came and she looked at couple of her slipper was lost and she said to Andhe that it was her slipper. And Andhe said to Yellow to be his wife (choice of words), but Yellow did not want to be his wife, actually she just wanted to look for his slipper (s) Dramatic Paragrah)

\section{Scene 1}

One day in the little house...

$\begin{array}{ll}\text { Red } & : \text { Yellow... take me a glass of drink... } \\ \text { Yellow } & : \text { yes sister.. Wait a moment... } \\ \text { Blue } & : \text { come here!! Neat my hair...!!! } \\ \text { Red } & : \text { neat my hair too... } \\ \text { Blue } & : \text { Yellow, quickly .... } \\ \text { Yellow } & : \text { my hand is only two... be patient... } \\ \text { Mother's Klenting } & : \text { Yellow, come here..These clothes are very dirty. } \\ \text { Yellow } & : \text { so, what???? } \\ \text { Mother's Klenting } & : \text { let's to wash ....stupid... } \\ \text { Yellow } & : \text { Yes mom.... }\end{array}$

\section{Scene 2}

Yellow was washing in the river, there was Andhe take a peep Yellow... Than Yellow hear a crowded. She surprised...

Yellow : What is it? (Quickly Yellow goes out from the river, but she is not aware that her slipper was left behind).

Oh my God... my slipper was lost..

Andhe : (Put Yellow's slipper) hmm, it is the girl's slipper. By the way how find the girl. Hmm,,.. advisable, I give announcement. 


\section{Scene 3}

Andhe Spread a leaflet and patched on the walls and trees in the village to announce about Sipper looking for prize contest which would be conduct.

Blue : Wow, there is a prize contest. Andhe Andhe wants to look for a wife.

Red : What? Andhe Andhe wants to look for a wife??? But, wwhat are the requirements?

Blue : It is very easy! Just show the couple of slipper that found by Andhe in the river.

Red : Haaa..... What kinds of requirement that? But, actually I want to be Andhe's wife.

Blue : So, what will we do? If we want to win the prize contest, we must have a same slipper like as slipper that found by Andhe.

Red : No problem. We will look for later, ok! Now, let's eating together, I'm very hungry.

They entered to the house and unintentionally they looked Yellow's Slipper which only one side, no other couple.

Blue : Look Yellow's behavior! Slipper just one side still be saved!

Red : Eh, wait! It's just one side?!

Red and Blue: May be?

Blue : Yellow! Yellow, come here quickly!

Yellow : Why do you call me my sister?

Red : What happen with this slipper? Why just one side?

Yellow : Ooo... The other side was lost in the river.

Blue : Haaa? It means that is right? (Blue say quietly to Red)

Red : OK! Please go out!

Right, it means that her slipper which is looked for by and he!

Blue : If that is right, lets we bring this slipper, for show to Andhe

Red : Ok! Lets we bring.

\section{Scene 4}

Confusion attack Andhe that think the girl slipper mine.

Andhe : Supposing I know who is slipper mine!

Mother's Andhe : What happen? Since yesterday you always dreaming?

Andhe : I'm confuse mom,. Think whose is slipper it. Yesterday I saw this slipper in the river. There was beautiful girl that left it.

Mother's Andhe : Is the girl beautiful? Will the girl become your wife?

Andhe : I hope mom. Now I look whose slipper it is.

Mother's Andhe : Yes, I just hope she is better for you, if you are happy, I'm happy too.

Andhe : Yes mom. Thanks. 


\section{Scene 5}

On the Klenting's House...

Red : Mom, we will to go to Andhe's house, we want to follow the prize contest.

Mother's Klenting : What is the prize contest?

Bluee

: Emmmsss He wants to look for a girl that has this slipper. (show the slipper)

Mother's Klenting : Who is slipper that?

Red : Yellow's mine! One of the slipper lost in the river. Then Andhe took it mom.

Blue : Andhe wants to look for it mine, and became his style.

Red : Yes mom, tt's better me or blue rather than kamseupay.

Mother's Klenting : Good my children. Ok, let's go be fast.

Red + Bluee: yes mom.

\section{Scene 6}

Yellow walked to the river, she look for the slipper..

Yellow : Huft, Where is the slipper? It should be in here..

After she was looking for in every corner in the river, and she didn't find it.So, she was very disappointed.

Yellow : I am so tired, perhaps my slipper washed away in the river.

Mother's Klenting : Hey, what do you look for?

Yellow : My slipper mom. I think I put in here.

Mother's Klenting : “(hah, certainly that slipper. She can't know that Blue and Red have been taken it!!". Ahh..it's not important,), let's wash the dirty pan in the river! I don't want to know, you must clean the plan without slain..

Yellow : (unlucky)! Ok... Ok..!

In the river, Yellow washing the pan hardly.....

Yellow : How it can be clean? It's very black.

\section{Scene 8}

Suddenly Angel appear..

Angel : don't worry Yellow, I can help you

Yellow : who are you?

Angel : I'm Angel. I will help you whenever you need.

Yellow : I commanded clean this pan. But the pan is very black.

Angel : it is very easy....

View minute later

Angel : this is... frontal side, back side,. Shiny, isn't it?

Yellow : thank you very much angel... 
Angel : Ok! You are welcome..

Yellow : I think it is different.

\section{Scene 8}

In the river Blue $\&$ Red confuse to across..

Blue : how to across it?

Red : Calm... I am sure that there is a way.

From distance, they look Yuyu...

Yuyu : hay girls... can I help you?

Red : we want to across the river, but there is not a way.

Yuyu : hahaha.... It's simple. I can help you, but you must give me repayment.

Red : what is the repayment?

Yuyu : the next, you ride to my back, I will help you to across. But, if until side, you must kiss me.

Red : ha???

Blue : no problem, rather than don't arrive in Andhe's house.

Red : ahh..we have no other way.

They arrive in side and give repayment to Yuyu.

\section{Scene 9}

After return the pan, Yellow come back, she knows these announcement and she read..then Yellow was surprise, because her slipper was brought by Andhe. Yellow goes to Andhe's house. She has through bridge that hidden for opposite to river face. Yellow arrive in Andhe's house.

Red : this is a slipper that you look for.

Andhe : who have this is?

Red : this is my slipper.

Bluee : my slipper

Red : my slipper

Red and Blue in fact quarrel take by force that slipper.

Andhe : although, the slipper is yours. I won't choose one of you. Yuyu kangkang has kiss you.

Red and Blue are angry and disappointed. They left Andhe's house and trough the slipper. Then Yellow came to Andhe's house and found a slipper that through by red and blue.

Yellow : Andhe,,,, where is my slipper?

Andhe : (unhisper) heeemssssssss, she like as the girl in a river. Who are you?

Yellow : I'm Yellow, whom has this slipper. Yesterday that one left behind. 
Using Local Drama in Writing and Speaking

Andhe $\quad:$ it means that you are a girl that I looked for.

Andhe introduce Yellow to her mother.

Andhe : mom, can I marry with Yellow?

Mother's Andhe $\quad$ : if you are ready. You can marry with yellow. I'm agree.

Andhe : Yellow, Will you become mother for my child?

Yellow : What?????

Andhe : I'm just kidding. Yellow, will you become my wife???

Yellow : no...!!!! I'm just look for my slipper. Because my slipper just one.

Andhe surprised...... 